\title{
Connecting Regional Governance, Urban Form, and Energy Use: Opportunities and Limitations
}

\author{
Arnab Chakraborty ${ }^{1}$ - Dustin Allred ${ }^{1}$
}

Published online: 10 July 2015

(C) Springer International Publishing AG 2015

\begin{abstract}
In this article, we explore the links between urban form, land use planning, and energy use. We organize the reviewed literature as follows: (1) potential energy savings from compact development; (2) achieving compact development through land use regulations; and (3) approaches for coordinating land use regulations regionally. We find that while the literature shows a clear link between regional governance, urban form outcomes, and energy use, questions remain on measuring the impact and communicating the degree to which energy use benefits can offset other real and perceived costs associated with greater land use regulation and regional coordination. Our discussion focuses on how researchers, practitioners, and policymakers can better leverage these connections.
\end{abstract}

Keywords Land use $\cdot$ Energy use $\cdot$ Regionalism $\cdot$ Urban form $\cdot$ Governance

\section{Introduction}

The energy consumption trends of urban areas threaten the resiliency of our cities and contribute to growing concerns about global climate change. In the US, urban areas account for approximately $75 \%$ of the total energy consumption with

This article is part of the Topical Collection on Urban Planning

Arnab Chakraborty

arnab@illinois.edu

Dustin Allred

dallred2@illinois.edu

1 Department of Urban and Regional Planning, University of Illinois, Urbana-Champaign, 611 Taft Drive, Champaign, IL 61820, USA residents directly consuming at least $40 \%$ of that for transportation and household purposes [1,2]. Globally, urban areas are estimated to account for more than $80 \%$ of total greenhouse gas (GHG) emissions [3, 4]. Energy expenditures in the US constitute a significant and rising share of regular household spending, with a disproportionate impact on lower income households $[5,6]$. Consumption in other parts of the world, though lower, shows similar upward trajectories [7]. Despite the technological innovations and efficiency gains, studies suggest that energy consumption will continue to increase due to lifestyle and demographic changes, increased wealth, and latent demand [8-10]. This has led researchers to conclude that realizing a reduction in urban energy use will require changes in social and spatial characteristics of human settlements $[2,11,12 \cdot]$.

Multiple studies have documented the ways in which land use policies can influence urban form and human behavior [2, 13-18]. Sorting through these can help identify the key linkages to energy use and the policy frameworks and scales of implementation that are more effective at exploiting them. For example, studies have shown growing evidence that coordination of land use policies at the regional scale can better account for the negative externalities of fragmented local land use policy and improve their ability to impact region-wide development outcomes $[2,19,20 \bullet]$. However, there remains a gap in our understanding about whether local efforts at energy savings are likely to be as effective without regional coordination and under what circumstances are regional efforts more likely to be successful.

In this article, we attempt to address this gap through a review of research-based literature, identifying areas where more research is needed. We cover a large yet scattered set of literature from three angles: (1) residential and travel energy savings from compact development; (2) land use planning and its influence on compact development; and (3) regional 
approaches in coordinating land use planning. We identify the key linkages between urban form and energy use as mediated through transportation demand, travel behavior, and household uses. We synthesize the land use and governance literature to identify those that take the most advantage of these linkages and likely barriers to their success. We conclude with a discussion setting a research agenda on how the knowledge gap can be further closed.

\section{The Energy Use and Urban Form Connections}

In this section, we look at the link between urban form and (1) transportation energy consumption and (2) residential energy consumption. From a transportation perspective, energy use is an outcome of factors, such as the number of trips, distance travelled, transportation mode used, etc. Although their relationship with land use is complex, a number of characteristics have been associated with travel demand and behavior. Multiple studies (see, for example, [21, 22]) including a recent and comprehensive review by the Transportation Research Board [2] found that compact urban areas have lower travel demand, particularly when both residential and employment densities are high and close to each other. Such arrangements make multiple transportation modes more viable, allow multipurpose trips and reduce travel distances [21], each contributing to the reduction in net energy consumption.

More direct studies [18, 23, 24] found that transportation energy consumption declines as density increases, both in multicity comparisons and in models of more compact growth scenarios. Others have added that the location (e.g., distance to city center) and type of density [25], and diversity or mix of land uses [26, 27•] are also important determinants of transportation energy consumption. For example, smaller lot sizes and parking availability are associated with patterns of consumption that include ownership of smaller cars and less energy-consuming multi-family housing units $[28,29]$. In a recent study on the effects urban form on transportation energy consumption in Baltimore, Maryland, Liu and Shen [17] found that characteristics of the built form are related both directly and indirectly to household energy use outcomes. Variations in the built environment were found to have a significant effect on VMT, especially when the built environment was represented by an accessibility measurement. The authors also noted modest indirect effects as household choose vehicle size and type based the neighborhood context. The TRB [2] study argues that these effects can be made even stronger when complemented with energy pricing policies and improved vehicle efficiencies.

The above findings have often been used to suggest the following: (a) the need for higher densities and mixed-use developments to reduce travel demand and (b) greater mode choices to reduce automobile trips $[2,13,30]$.
Studies have also looked at the link between characteristics of urban form and residential energy use. In an average household, physical characteristics: the size of the structure [31-33], space heating and cooling, water heating, and lighting [5, 34-36]; household demographics [9, 38], appliances in use [35], and climatic variability [31] have been shown to be critical determinants of household energy use patterns. Pitt [37•], in a recent study of climate action planning, found that a compact housing scenario for future urban growth could decrease residential energy us by as much as $36 \%$. According to Brown and Southworth [5], approximately $63 \%$ of houses in the USA are single-family detached units, accounting for $73 \%$ of residential energy consumption. Schipper et al. [38] estimate that housing characteristics account for approximately $50 \%$ of a home's energy use, while household characteristics and their lifestyle activities account for the remaining amount. The characteristics of residential structures themselves often vary with urban form and land use policy. Controlling for other influences, Ewing and Rong [19] found that residents of low-density developments were more likely to live in larger single-family detached houses than comparable residents in a more compact development and that larger, detached houses use more energy because there is both more space to heat and cool as well as more exposed surface area subject to thermal loss. Further, they note that the median square footage of new housing has been steadily increasing, facilitated by less constrained land supplies and larger lots in the suburbs. While these studies demonstrate how land use shapes residential energy consumption, studies by Andrews [39] and Kaza and Curtis [40•] have explored how land use patterns and policy impact energy consumption by way of either promoting or hindering different types of energy production that could result in more efficient and sustainable use (e.g., smart networks that make distributed and renewable generation viable).

Another challenge is the inequitable burden of energy costs that the existing urban form places on low-income residents. While energy consumption patterns of low-income households are generally assumed to be similar to average households, a case-control study of energy use among low-income households [41] has found that significant variation in the "maintained interior temperature between households" could only be attributed to behavioral differences among the occupants. This suggests higher vulnerability of low income households to both energy prices as well as policy interventions that disregard different risks and behavioral characteristics. Hackett and Lutzenhiser [42] have called it the balancing of an "engineering approach" to residential energy consumption with a more "behavioral approach." Built environment patterns sometimes force low-income households to choose locations and structures where they spend a higher share of their incomes on energy which increases their vulnerability to fluctuations in the price of energy [26, 43]. A study by Sharpe 
[44] found that decentralized patterns of development have left the residents of auto-centric suburbs especially vulnerable to increases in the cost of fuel. These fluctuations are particularly troublesome for low-income households who lack the flexibility to absorb an increase in transportation costs without limiting their mobility.

Modifying these energy use outcomes will require a number of changes to current urban policy practices. In addition to direct approaches such as targeted pricing schemes that reduce usage [45], other measures are needed. They may include expanding the adoption of more energy-efficient green building codes, upgrading older structures for better energy efficiency and planning for an urban form that provides choices in housing types beyond the ubiquitous single-family detached housing $[5,33]$.

In summary, a number of urban form characteristics can be implicated in the energy use outcomes or urban areas, most commonly, density, mix of building types, spatial arrangement of uses, urban design, and accessibility of transportation networks. Most of these show a strong connection between compactness of urban form and a reduction in energy use. For example, the TRB [2] study concludes that increasing residential density across a metropolitan area by a factor of two could lower VMT by about 5 to $12 \%$ and perhaps by as much as $25 \%$ if efforts to restrict low density development are coupled with other demand-side policies and infrastructure investments.

The specific urban form characteristics, however, are outcomes of numerous interlinked phenomena occurring at multiple scales. They range from neighborhood scale energyefficiency requirements to municipal zoning requirements and metropolitan scale issues like constructing regional transit systems. Although individual units of governments can - and do - adopt policies to address these linkages, the effect is often blunted by externalities not contained within their jurisdictional boundaries. For example, an attempt to increase density or limit fringe growth in one city may simply shift growth to another city within the region [46]. Similar effects can be expected of isolated policies to increase energy efficiency of buildings or pricing of externalities. This suggests that urban form interventions to affect energy use should be coordinated at the regional scale for better policy efficacy and collective regional outcomes, matching land use policy coordination to the scale at which labor markets, commute sheds and housing markets operate [47-51].

\section{Urban Form and Land Use Regulations}

This section discusses the links between land use regulations and urban form. We specifically focus on those characteristics of each that are closely related energy use, such as land use zoning, infrastructure, and regional coordination efforts driven by an interest in "sustainability."

Land use zoning impacts household location and type. Restrictive zoning and subdivision ordinances in many suburban jurisdictions have been criticized for promoting larger houses, protecting local privilege, discouraging multi-family developments, and mixed use developments, [52-56]. These have led to patterns of development that push residents further away from jobs, increasing auto-dependence for most non-homebased activity. Uncoordinated controls in one city also tend to export unwanted growth and its attendant ills to neighboring communities [52]. The result is a political climate in which local governments use land use policy to maintain property values, attract certain kinds of growth, and avoid increased tax burdens - often leading to greater vehicle miles traveled and increasing energy demands.

Inefficient infrastructure planning or the lack of coordination between land use and transportation planning can result in development patterns that lead to longer travel times, greater congestion, and higher energy consumption. Conversely, provision of transportation alternatives with complementary land use policies such as high-density zoning has been closely linked to development types that are more compact. Transitoriented developments (TODs) have been known to promote these principles. Cervero and Arrington's [13] study of 17 TODs across five US metropolitan areas showed that car trips generated - and by extension, energy consumed - per household in TODs were significantly lower than standard rates estimated by the Institute of Transportation Engineer's manual. TODs and other travel-related energy-reducing practices are, however, currently only a small portion of the development landscape, and their effect is blunted by a lack of coordination across municipal boundaries in a metropolitan area.

Lack of regional coordination has been for a variety of urban form outcomes with many linkages to energy use outcomes. Fragmentation in land use regulations have been shown to affect density, urbanized land area, property values, and public expenditures on infrastructure $[57,58]$. In their study of growth in the Barcelona Metropolitan Region of Spain over the last 25 years, Paül and Tonts [59] found that fragmented planning at the municipal has largely failed to halt the sprawling consumption of productive agricultural lands. Resulting competition between local government is also blamed for creating inefficiencies by limiting gains from scale economies in service provision $[52,60,61]$ and underinvestment on public goods that would benefit the entire region [47, 57, 58]. As discussed before, many of these outcomes increase energy consumptions, and impose especially high burden on low-income communities.

While a number of attempts have been made for better coordination, the outcomes have not always been as desired. For example, federal legislations such as, the Intermodal Surface Transportation Efficiency Act (ISTEA) and the 
Transportation Equity Act for the 21st Century (TEA-21) required coordinated regional planning for transportation infrastructure investment. However, land use policy has been largely left under the control of local municipalities and often uncoordinated with regional transportation decisions. Studies of infrastructure investments advanced with the goal of relieving congestion and reducing emissions show that such measures often induced more traffic and facilitated more sprawl before reaching a new congested equilibrium [62].

The above discussion illustrates how certain practices lead to land use patterns that consume higher levels of energy. Although the planning literature presents regional governance as a more flexible and responsive, better equipped to deal with unsustainable urban growth, it has not gone unchallenged. Some critics suggest that developers are better able to satisfy market demand in a fragmented governance structure that reflects Tiebout's [63] public choice theory of urbanizationdemand they characterize as favoring low density single family housing in the suburbs $[22,64]$. Conversely, in Myers and Gearin's [65] study of demand for denser residential environments, survey data was used to capture a more nuanced picture of housing demand, showing a growing interest in more traditional neighborhood developments as a result of demographic change. Similar studies by Storper and Manville [66] and Song and Knaap [67] show that households are in fact willing to pay a premium for denser communities, which may be more energy efficient.

\section{Regional Planning Frameworks, Governance, and Energy Use}

Efforts to address energy use through land use policy are occurring at multiple scales. At the federal level, the US Department of Housing and Urban Development (HUD) recently created the Office of Sustainable Housing and Communities to foster the development of Regional Plan(s) for Sustainable Development across the nations [68]. Part of its mission is to better coordinate land use policy with housing and transportation investments at a regional scale to effect a reduction in residential energy costs [68]. However, participation in this program is voluntary, and no clear guidelines are provided as to what should be included in the Regional Plan [69]. Several states have also attempted to promote smart growth policies linking land use policy to energy use outcomes. These efforts underscore the fact that, to date, state-level mandates and incentives have been the main drivers of successful regional coordination in the USA.

More recently, metropolitan areas facing bleak choices with regard to accommodating projected growth and infrastructure needs have turned to a voluntary form of regional cooperation utilizing existing institutional structures, such as Metropolitan Planning Organizations (MPOs) and Councils of
Government (COGs). While there are some notable examples of voluntary regional land use planning (see Denver's Mile High Compact, Envision Utah, Oregon Shines, Chicago Metropolis 2020, and California's Blueprint), little is known about how this emerging form of regionalism is affecting both patterns of metropolitan development and performance outcomes like energy consumption.

Some studies, primarily focused on efforts in Europe, have documented the impact of regional planning and policy on development outcomes [70, 71]. In that context, the authors suggest that regional governance first emerged in the interest of exploiting economic opportunities but has more recently become concerned with the environmental and social impacts of economic restructuring and spatial development. In their review of recent European regional planning efforts, Albrechts et al. [70] find a renewed interest in strategic spatial planning combining economic, environmental, and social objectives to address quality of life concerns in response to emerging sub-national place identities. Examples include elected, centralized administrative arrangements of cityregions in Germany, a spatial structure plan for multiple urban regions in Belgium altering the legal framework of local land use planning, and a spatial development strategy for Northern Ireland. Results of these efforts suggest that the strategic concepts of regional spatial planning have been translated into land use plans used to guide a more sustainable public and private development in a politically acceptable way [70, 71]. Studies on the organizational structures and success of regional institutions have presented opportunities to compare their impacts on local plans, planning culture, land use policies, and development outcomes.

Land use-related regional efforts in the USA that discuss energy consumption as an explicit driver, however, are very limited. Among state-level initiatives, the state of California recently passed legislation, SB 375, aimed at redesigning the built environment of communities through regional coordination to reduce energy consumption. In this framework, municipalities are expected to work together on regional land use plans that provide a wider range of transportation and housing choice to residents $[72,73]$. As an example of a state-level mandate $^{1,2}$, this legislation attempts to use regional MPOs more proactively, matching transportation investments to a normative vision of future land use in contrast to what has in the past been a reactive process [74]. California SB 375 directs the state Air Resources Board (ARB) to set greenhouse gas (GHG) reduction targets and to work with MPOs to "align

\footnotetext{
${ }^{1}$ It should be noted that mandates such as these have come under heave scrutiny due to the recent recession and condition of state and federal budgets. At the time of writing, the federal and California governments were considering removing funding for these potentially landmark programs.

${ }^{2}$ References to actual cases are used primarily to illustrate our theoretical argument, not to provide empirical evidence based on a case study methodology.
} 
their transportation, housing, and regional land-use plans with greenhouse gas reductions in mind" [73•]. As a result, the initial round of non-binding plans produced in compliance with SB 375 used a mix of smart growth ideas to chart an alternative future for metropolitan growth that reduces energy use and GHG emissions [75•]. Other states have tried to promote regional coordination in a suite of growth management policies. Although not explicitly aimed at reducing energy consumption, these policies have sought to address externalities of urban development. Florida's Growth Management Act of 1985 requires consistency and concurrency between land use and transportation plans, and development permits [76]. Maryland's Priority Funding Act of 1997 provides fiscal incentives to local governments to influence the location of new infrastructure consistent with smart-growth principles. Studies by Chapin [77], Dierwetcher [78], and Lewis et al. [79], among others, show varying degrees of coordination employed in a smart growth planning paradigm, although outcomes have generally been less than expected in terms of affecting more compact patterns of metropolitan growth.

\section{Conclusion}

Current urban growth trends and land use planning structures in the US exacerbate the energy needs of our cities. The uncertainty of future energy prices and their inequitable impact on vulnerable populations add to the urgency of addressing this problem. Studies have shown that local efforts at energy savings are likely to be ineffective unless they are coordinated with a regional approach. However, municipal governments lack the incentives to cede land use authority to regional agencies. In a perceived economy of globalized competition, land use control is seen as yet another way municipalities can vie with each other for increases in growth, tax revenue, and resources. Nonetheless, attempts at regional planning to achieve energy use and climate change mitigation goals are growing. Variations by regions and their complexity have led to a wide variety of alternative and complementary paths to regional actions. However, many of them lack clear goals, making it difficult to assess their efficacy.

Regional transportation planning in the USA is now supported by federal mandates and fiscal incentives, and these combine to successfully overcoming the parochial interests of local jurisdictions. Land use planning at the regional scale, despite its apparent potential to better achieve energy reduction goals, has received no such mandate and must rely on the sense of a shared future among regionally connected stakeholders. The scenario planning and visioning processes increasingly employed by regional entities like COGs or even MPOs reflect this dynamic. These processes acknowledge local control of zoning and land use policy while attempting to affect a change in subjectivity and an awareness of interconnectivity among stakeholders. Issues such as regional quality of life or environmental preservation are invoked as motivations for intervention with the intention of encouraging local changes to land use policy that affect regional outcomes. However, it remains to be seen what effect regional governance, absent a strong state of federal mandate and the support of fiscal incentives, can have on spatial patterns of development over the long run. More research is needed to better understand the pathways and processes along which this change in the willingness of local governments to prioritize regional sustainable development goals occurs and under what conditions it results in more sustainable outcomes over the long-term. Can the diverse positions and needs of different cities really be reconciled in a regional vision? In addition, how do higher level mandates add to or hinder these processes? For example, California's recently passed SB 375 effectively mandates a regional process. However, it still relies on a framework of voluntary governance, and the fiscal incentives it provides may not by substantial enough to affect a change in the way land use policy is set at the local level.

In the end, there are clear connections between urban form and energy use, and there are benefits to thinking about them together from a land use planning perspective, especially at a regional scale. As our review shows, there are many examples of land use plans and policies that promote more compact development-locally and regionally - in a variety of contexts through density minimums, smaller lot sizes, TOD, inclusionary zoning, growth boundaries, and infrastructure investment. Despite such evidence, land use planning remains relatively minor contributor in the discourse on energy planning, primary because regional scale coordination is a necessary aspect of gaining energy efficiency, and regional coordination is often politically unpopular in the USA.

Compliance with Ethics Guidelines

Conflict of Interest The authors declare that they have no competing interest.

Human and Animal Rights and Informed Consent This article does not contain any studies with human or animal subjects performed by any of the authors. 


\section{References}

Paper of particular of interest, published recently, have been highlighted as:

- Of importance

1. United States Energy Information Administration (EIA). Annual energy review. Washington, DC: United States Department of Energy; 2007.

2. Transportation Review Board (TRB). Driving and the built environment: the effects of compact development on motorized travel, energy use, and CO2 emissions - special report 298. Oak Ridge: Oak Ridge National Laboratory (ORNL); 2009.

3. Dodman D. Blaming cities for climate change? An analysis of urban greenhouse gas emissions inventories. Environ Urban. 2009;21(1):185-201.

4. Hoornweg D, Sugar L, Gomez CLT. Cities and greenhouse gas emissions: moving forward. Environ Urban. 2011;0956247810392270.

5. Brown MA, Southworth F. Mitigating climate change through green buildings and smart growth. Environ Plan A. 2006;40(3): 653-75.

6. Roberts S. Energy, equity and the future of the fuel poor. Energy Policy. 2008;36(12):4471-4.

7. IPCC 2007, Climate Change 2007: impacts, adaptation and vulnerability. Summary for policymakers. Contribution of working group II to the fourth assessment report of the intergovernmental panel on climate change. Summary approved at the 8th session of working group II of the IPCC, Brussels.

8. International Energy Agency (IEA). World energy outlook 2008. Paris: OECD/IEA; 2008.

9. Weber C, Perrels A. Modelling lifestyle effects on energy demand and related emissions. Energy Policy. 2000;28(8):549-66.

10. Wright $\mathrm{A}$. What is the relationship between built form and energy use in dwellings? Energy Policy. 2008;36(12):4544-7.

11. Ewing R, Bartholomew K, Winkelman S, Walters J, Chen D. Growing cooler: the evidence on urban development and climate change. Washington, DC: Urban Land Institute; 2008.

12. Hamidi S, Ewing R. A longitudinal study of changes in urban sprawl between 2000 and 2010 in the United States. Landsc Urban Plan. 2014;128:72-82. The study finds that metropolitan sprawl increased between 2000 and 2010, and that this increase has implications for transportation outcomes.

13. Cervero R, Arrington GB. Vehicle trip reduction impacts of transitoriented housing. J Public Transp. 2008;11(3):1-17.

14. Bednar-Friedl B, Koland O, Steininger KN. Urban sprawl and policy responses: a general equilibrium analysis of residential choice. $\mathrm{J}$ Environ Plan Manag. 2011;54(1):145-68.

15. Ewing R, Cervero R. Travel and the built environment: a synthesis. Transp Res Record: J Transp Res Board. 1780;2001:87-114.

16. Ewing R, Pendall R, Chen D. Measuring sprawl and its impact. Washington, DC: Smart Growth America; 2002.

17. Liu C, Shen Q. An empirical analysis of the influence of urban form on household travel and energy consumption. Comput Environ Urban Syst. 2011;35(5):347-57.

18. Newman P, Kenworthy JR. Sustainability and cities: overcoming automobile dependence. Washington, DC: Island Press; 1999.

19. Ewing R, Rong F. The impact of urban form on US residential energy use. Hous Policy Debate. 2008;19(1):1-30.

20. Wheeler SM, Tomuta M, Haden VR, Jackson LE. The impacts of alternative patterns of urbanization on greenhouse gas emissions in an agricultural county. J Urban: Int Res Placemaking Urban Sustain. 2013;6(3):213-35. The study models two alternative 2050 outcomes for Yolo County, CA using two IPCC storylines and finds very different long term GHG outcomes. It also models a third scenario, infill development, and finds that GHG emissions can be further reduced through urban form outcomes.

21. Crane R. The influence of urban form on travel: an interpretive review. J Plan Lit. 2000;15(1):3.

22. Gordon P, Richardson HW. Are compact cities a desirable planning goal? J Am Plan Assoc. 1997;63(1):95-106.

23. Kenworthy JR. Energy use and $\mathrm{CO} 2$ production in the urban passenger transport systems of 84 international cities: findings and policy implications. Urban Energy Transit: Fossil Fuels Renew Power. 2011;211-35.

24. Hankey S, Marshall JD. Impacts of urban form on future US passenger-vehicle greenhouse gas emissions. Energy Policy. 2010;38(9):4880-7.

25. Mindali O, Raveh A, Salomon I. Urban density and energy consumption: a new look at old statistics. Transp Res A Policy Pract. 2004;38(2):143-62.

26. Owens SE. Energy, planning and urban form. Pion London. 1986.

27. Yin Y, Mizokami S, Maruyama T. An analysis of the influence of urban form on energy consumption by individual consumption behaviors from a microeconomic viewpoint. Energy Policy. 2013;61: 909-19. This study finds that higher employment density areas served by mass transit can improve energy efficiency.

28. Dale VH. The relationship between land-use change and climate change. Ecol Appl. 1997;7(3):753-69.

29. Ewing R, Kostyack J, Chen D, Stein B, Ernst M. Endangered by sprawl: how runaway development threatens America's wildlife. Washington, DC: National Wildlife Federation, Smart Growth America, and Nature Serve; 2005.

30. Cervero R, Kockelman K. Travel demand and the 3Ds: density, diversity, and design. Transp Res Part D: Transp Environ. 1997;2(3):199-219.

31. Kaza N. Understanding the spectrum of residential energy consumption: a quantile regression approach. Energy Policy. 2010;38(11):6574-85.

32. Wilson A, Boehland J. Small Is beautiful: US house size, resource use, and the environment. J Ind Ecol. 2005;9(1-2):277-87.

33. Kahn ME. The environmental impact of suburbanization. J Policy Anal Manag. 2000;19(4):569-86.

34. Randolph J, Masters GM. Energy for sustainability: technology, planning and policy. Washington, DC: Island Press; 2008.

35. Rong, F. Impact of urban sprawl on US residential energy use. Doctoral Dissertation, University of Maryland. 2006.

36. El-Khawas IN. The optimal design of buildings: A life-cycle approach to energy efficiency. 1997. Unpublished doctoral dissertation, The Ohio State University, Columbus, $\mathrm{OH}$.

37. Pitt D. Assessing energy use and greenhouse gas emission savings from compact housing: a small-town case study. Local Environ. 2013;18(8):904-20. The study finds that single family detached homes consume significantly more energy than multi-family structures and, using the case of Blackburg, VA shows the specific energy and GHG gains that can be had by promoting compact, multifamily residential developments in the future.

38. Schipper L, Bartlett S, Hawk D, Vine E. Linking life-styles and energy use: a matter of time? Annu Rev Energy. 1989;14(1):273320 .

39. Andrews CJ. Energy conversion goes local: implications for planners. J Am Plan Assoc. 2008;74(2):231-54.

40. Kaza N, Curtis MP. The land use energy connection. J Plan Lit. $10.1177 / 0885412214542049$. This study finds that planners should promote practices that lead to greater renewable energy production and suggests that this will be an important complement to the efforts on reducing energy consumption.

41. Parker DS, Mazzara MD, Sherwin JR. Monitored energy use patterns in low-income housing in a hot and humid climate. In Tenth 
Symposium on Improving Building Systems in Hot Humid Climates 1996;316.

42. Hackett B, Lutzenhiser L. Social structures and economic conduct: interpreting variations in household energy consumption. Sociol Forum. 1991;6(3):449-70.

43. Pastor MT, Lester W, Scoggins J. Why regions? Why now? Who cares? J Urban Aff. 2009;31(3):269-96.

44. Sharpe R. Energy efficiency and equity of various urban land use patterns. Urban Ecol. 1982;7(1):1-18.

45. Hirst E. Analysis of residential energy use. Int J Energy Res. 1978;2(1):73-83.

46. Bento A, Lowe S, Knaap G-J, Chakraborty A. Housing market effects of inclusionary zoning. Cityscape. 2009;7-26.

47. Basolo V. US regionalism and rationality. Urban Stud. 2003;40(3): 447-62.

48. Dierwechter Y. Metropolitan geographies of US climate action: cities, suburbs, and the local divide in global responsibilities. $\mathrm{J}$ Environ Policy Plan. 2010;12(1):59-82.

49. Forster K. A region of one's own. In: Ethan S, Armando C, editors. Regional planning in America: practice and prospect. Cambridge: Lincoln Institute of Land Policy; 2011.

50. Swanstrom T. What we argue about when we argue about regionalism. J Urban Aff. 2001;23(5):479-96.

51. Wheeler SM. The new regionalism: key characteristics of an emerging movement. J Am Plan Assoc. 2002;68(3):267-78.

52. Downs A. New visions for metropolitan America. Washington, DC: Brookings Institution Press; 1994.

53. Levine JN. The role of economic theory in regional advocacy. J Plan Lit. 2001;16(2):183.

54. Nelson AC. Characterizing exurbia. J Plan Lit. 1992;6(4):350.

55. Quigley JM, Rosenthal LA. The effects of land use regulation on the price of housing: What do we know? What can we learn? Cityscape. 2005;69-137.

56. Shlay AB, Rossi PH. Keeping up the neighborhood: estimating net effects of zoning. Am Sociol Rev. 1981;46(6):703-19.

57. Carruthers JI, Ulfarsson GF. Fragmentation and sprawl: evidence from interregional analysis. Growth Chang. 2002;33(3):312-40.

58. Razin E, Rosentraub M. Are fragmentation and sprawl interlinked? North American evidence.”. Urban Aff Rev. 2000;35(6):821-36.

59. Paül V, Tonts M. Containing urban sprawl: trends in land use and spatial planning in the metropolitan region of Barcelona. J Environ Plan Manag. 2005;48(1):7-35.

60. Rusk D. Cities without suburbs. Washington, DC: Woodrow Wilson Center Press; 1993.

61. Rusk D. Inside game outside game: Winning strategies for saving urban America. Brookings Institution Press. 1999

62. Cervero R. Road expansion, urban growth, and induced travel: a path analysis. J Am Plan Assoc. 2003;69(2):145-63.
63. Tiebout CM. A pure theory of local expenditures. J Polit Econ. 1956;64(5):416-24.

64. Ahluwalia G. Public attitudes toward growth. Hous Econ. 1999;47(5):7-13.

65. Myers D, Gearin E. Current preferences and future demand for denser residential environments. Hous Policy Debate. 2001;12(4): 633-59.

66. Storper M, Manville M. Behaviour, preferences and cities: urban theory and urban resurgence. Urban Stud. 2006;43(8):1247-74.

67. Song Y, Knaap G-J. New urbanism and housing values: a disaggregate assessment. J Urban Econ. 2003;54(2):218-38.

68. U.S. Department of Housing and Urban Development. Office of Sustainable Housing and Communities, [online] Available from http://portal.hud.gov/hudportal/HUD?src=/program_offices/ sustainable housing communities. [Accessed 17 February 2013].

69. Chakraborty A, Kaza N, Knaap G-J, Deal B. Robust plans and contingent plans: Scenario planning for an uncertain world. J Am Plan Assoc. 2011;77(3):251-66.

70. Albrechts L, Healey P, Kunzmann KR. Strategic spatial planning and regional governance in Europe. J Am Plan Assoc. 2003;69(2): 113-29.

71. Newman P. Changing patterns of regional governance in the EU Urban Stud. 2000;37(5-6):895-908.

72. Ewing, R., Meakins, G., Bjarnson, G., \& Hilton, H. (2011). Transportation and land use. In Making Healthy Places (pp. 149169). Island Press/Center for Resource Economics.

73. California Air Resources Board. Senate Bill 375. 2008. Accessed November 21, 2014. http://www.arb.ca.gov/cc/sb375/sb375.htm.

74. Barbour E, Teitz MB. Blueprint planning in California: forging consensus on metropolitan growth and development. San Francisco: Public Policy Institute of California San Francisco; 2006.

75. Barbour E, Deakin EA. Smart growth planning for climate protection: evaluating California's Senate Bill 375. J Am Plan Assoc. 2012;78(1):70-86. This study finds that California's Senate Bill 375, a legislation to reduce GHG emissions through more efficient development is poorly supported and its preliminary outcomes, despite rise in climate planning activities, suggests gaps between analysis and action.

76. Gale DE. Eight state-sponsored growth management programs: a comparative analysis. J Am Plan Assoc. 1992;58(4):425-39.

77. Chapin TS. Local governments as policy entrepreneurs. Urban Aff Rev. 2007;42(4):505.

78. Dierwechter Y. Urban growth management and its discontents. Palgrave Macmillan. 2008.

79. Lewis R, Knaap G-J, Sohn J. Managing growth with priority funding areas: a good idea whose time has yet to come. J Am Plan Assoc. 2009;75(4):457-78. 